\title{
Demography, genetic diversity, and population relationships among Argentinean Mapuche Indians
}

\author{
Alicia S. Goicoechea ${ }^{I}$, Francisco R. Carnese ${ }^{l}$, Alicia L. Caratini ${ }^{l}$, Sergio Avena ${ }^{l}$, \\ Maria Salaberryl ${ }^{l}$ and Francisco M. Salzano ${ }^{2}$
}

\begin{abstract}
Fertility, mortality and migration data from four Mapuche Indian communities located along a 215-km NE-SW linear area in the Province of Río Negro, Argentina, were collated with genetic information furnished by nine blood group systems and by mtDNA haplogroups. The demographic and genetic data indicated a clear dichotomy, which split the four populations into two groups of two. Differing degrees of non-Indian exchanges was probably the main determining factor for this separation. Total genetic variability was very similar in all groups, and the interpopulational variability accounted for only $10 \%$ of the total variability. A low prevalence of the Diego(a) antigen among the Mapuche was confirmed. The fact that significant genetic heterogeneity and population clusters were found in such a small territorial region attests to the sensitivity of demographic and genetic approaches in unraveling human history.
\end{abstract}

\section{INTRODUCTION}

The Mapuche Indians have been the subject of several demographic and genetic studies, the first surveys dating back to the 1930s (reviewed in Haas et al., 1985; Carnese et al., 1996). Our investigations started in 1990, with studies of several communities in Río Negro Province, Argentina. The first investigation was conducted in Blancura Centro, and included demographic and genetic (blood groups, other blood protein loci) data (Carnese $e t$ al., 1993, 1996). Other analyses involved the HLA system and mtDNA polymorphisms, surveyed in Anecón Grande, Cerro Policía and Aguada Guzmán (Ginther et al., 1993; Baillet et al., 1994). We made additional demographic and genetic studies of the latter three communities and compared the results with previous findings.

\section{SUBJECTS AND METHODS}

The four localities are distributed in a NE-SW orientation, as follows: 1) Aguada Guzmán (685' W, 39³0’S) and 2) Cerro Policía $\left(68^{\circ} 37^{\prime} \mathrm{W}, 39^{\circ} 10^{\prime} \mathrm{S}\right)$, both located in the Department of El Cuy, near the urban reference center of General Roca (165 km and $110 \mathrm{~km}$, respectively), 3) Blancura Centro (69 $\left.29^{\circ} \mathrm{W}, 40^{\circ} 30^{\prime} \mathrm{S}\right)$, also in the Department of El Cuy and 4) Anecón Grande ( $\left.70^{\circ} 22^{\prime} \mathrm{W}, 41^{\circ} 20^{\prime} \mathrm{S}\right)$, Department of 25 de Mayo (Figure 1). The latter two communities are more distant from General Roca $(325 \mathrm{~km}$ and $200 \mathrm{~km}$, respectively). The people of Blancura Centro and Anecón Grande do not share their habitat with mestizo groups, the settlement pattern being of the dispersed type
(Vapñarsky, 1983). The domestic units consist of nuclear and, in a few cases, extended families. In Cerro Policía and Aguada Guzmán, on the other hand, the settlement pattern is of the clustered type (Vapñarsky, 1983). Their villages are temporary sites in the movement towards urban centers (Caratini et al., 1995), thus favoring contact with non-Indians.

All localities are situated in a semi-desert region, the Patagonian steppe. The climate is cold and dry, with extreme temperatures ranging from $-33^{\circ}$ to $+40^{\circ} \mathrm{C}$. There is little rain; however, snow storms throughout the year bring water after melting. In the winter, the communities become isolated because of blocked roads.

In all communities, the demographic information was obtained by house visits with parallel clinical examinations (data not shown), as described in Carnese et al. (1996). Approximately $20 \mathrm{ml}$ of blood was collected in sterile tubes with anticoagulant (ACD) from representative individuals of each community. The blood samples were sent by air mail on the same day to Buenos Aires, where they were processed in the Hematology and Hemotherapy Laboratory of the Clinical Hospital, University of Buenos Aires. Blood group typing was performed within 24-72 h of collection using standardized methods.

Allele frequencies for the $\mathrm{ABO}, \mathrm{MNS}$ and Rh systems were obtained using the MAXLIK program of Reed and Schull (1968), while for the other blood groups, classic square root methods were used. Interethnic admixture was calculated using the ADMIX program (Chakraborty, 1975). The Mapuche population of Pedregoso, Chile (Etcheverry et al., 1967) was considered as representative of the origi- 


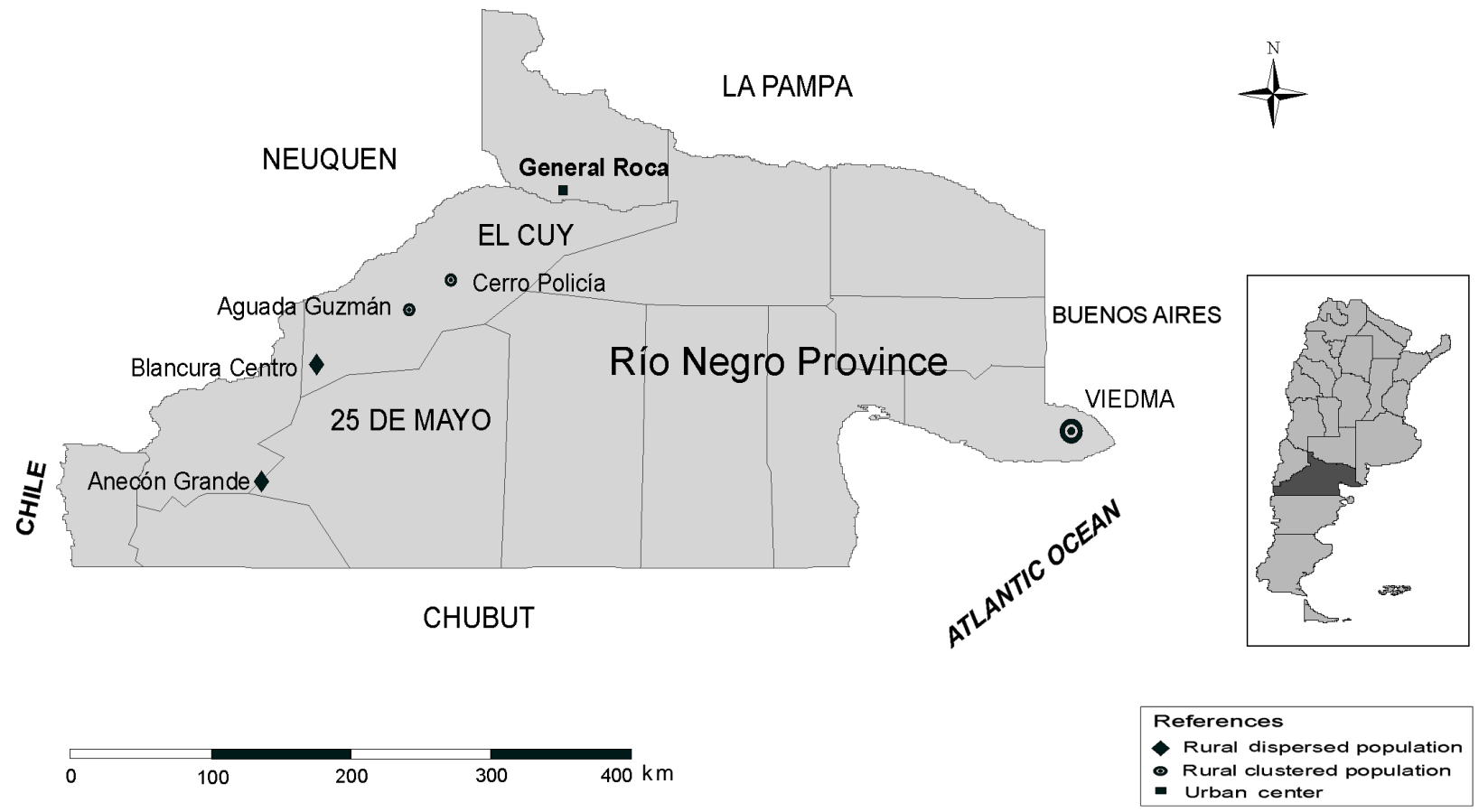

Figure 1 - Map of Río Negro Province, Argentina, showing the geographic location of the populations studied. The map of Argentina, bottom right, indicates the position of this province in the country.

nal Amerindian gene pool, while for the parental Spanish population the frequencies listed in Valls (1975) were used. The mtDNA data were obtained from previously published sources (Ginther et al., 1993; Bailliet et al., 1994). The demographic and protein results for Blancura Centro were taken from Carnese et al. (1996). Inter- and intrapopulational genetic variability and genetic distances were obtained following the methods of Nei $(1973,1978,1986)$, Nei et al. (1983), and Nei and Roychoudhury (1993). The dendrogram was obtained by the neighbor-joining procedure (Saitou and Nei, 1987), using the DISPAN program (Ota, 1993).

\section{RESULTS}

There was a clear dichotomy in types of marriage when the two localities with a more traditional way of life (Blancura Centro, Anecón Grande) were compared with the other two (Table I). Endogamy was higher (42-68\% vs. $14 \%$ ) and the proportion of interethnic unions lower (13$28 \%$ vs. $79-81 \%$ ). In all populations, the sexes were evenly distributed among immigrants and emigrants. As expected, those who left their communities were young and were distributed among a vast array of localities. Interchange between the communities considered here was limited, with only one known case which involved a woman who migrated from Aguada Guzmán to Cerro Policía.

Fertility was high in three of the four populations (about 7-8 children per mother who completed reproduc- tion), the exception being the number observed in Aguada Guzmán which was significantly lower than those at the other locations (Table II). The prevalence of premature deaths was not high (11-17\%) for rural Third World populations. The index of opportunity for selection, which conveniently summarizes in a single number fertility and mortality data, was also not high (Table II). The differences observed were too small to be considered significant (Adams and Smouse, 1985).

The presence of the blood group alleles $\mathrm{ABO} * \mathrm{~A}$, ABO*B, LU*A and KELL*K was associated with non-Indian antecedents (Table III). The relatively low prevalences of $\mathrm{P}^{*} 1$ and $\mathrm{DI} * \mathrm{~A}$, and the high incidence of $\mathrm{RH}^{*} \mathrm{RO}$ were notable. The dichotomy observed in the demographic data was also present in these results, with the groupings Anecón Grande and Blancura Centro versus Cerro Policía and Aguada Guzmán showing much more intragroup than intergroup similarity.

Differences in mtDNA haplogroup distribution in three of the localities investigated were not marked in haplogroups A-D, with the exception of the high prevalence of D in Aguada Guzmán (Table IV). On the other hand, haplogroup E was not found in Anecón Grande, but was present in the other two locations.

Total genetic variability $(\mathrm{Ht})$ was very similar in all groups ( 0.22 considering all of them together), and interpopulational variability accounted for only $10 \%$ of this value. Most of the variability was due to MNSs (Ht: 0.62) and Rh (Ht: 0.61), while Kell (Ht: 0.004) appeared at the other ex- 
Table I - Types of marriages and migration data for the Argentinean Mapuche populations studied.

\begin{tabular}{|c|c|c|c|c|c|c|c|c|}
\hline \multirow{3}{*}{$\begin{array}{l}\text { Types of marriages and migration data } \\
\text { 1. Classified by place of birth }\end{array}$} & \multicolumn{8}{|c|}{ Localities } \\
\hline & \multicolumn{2}{|c|}{ Blancura Centro* } & \multicolumn{2}{|c|}{ Anecón Grande } & \multicolumn{2}{|c|}{ Cerro Policía } & \multicolumn{2}{|c|}{ Aguada Guzmán } \\
\hline & $\mathrm{N}$ & $\%$ & $\mathrm{~N}$ & $\%$ & $\mathrm{~N}$ & $\%$ & $\mathrm{~N}$ & $\%$ \\
\hline Both partners from the same village & 38 & 68 & 8 & 42 & 6 & 14 & 3 & 14 \\
\hline One partner from another population & 14 & 25 & 8 & 42 & 9 & 22 & 7 & 32 \\
\hline Both partners from another population & 4 & 7 & 3 & 16 & 27 & 64 & 10 & 54 \\
\hline Total number of marriages & 56 & 100 & 19 & 100 & 44 & 100 & 20 & 100 \\
\hline \multicolumn{8}{|l|}{ 2. Classified by ethnic group } & - \\
\hline Indian x Indian & 49 & 87 & 13 & 72 & 7 & 19 & 4 & 21 \\
\hline Indian $\mathrm{x}$ mestizo & 7 & 13 & 1 & 6 & 10 & 26 & 5 & 26 \\
\hline Mestizo x mestizo & - & - & 4 & 22 & 21 & 55 & 10 & 53 \\
\hline Total & 56 & 100 & 18 & 100 & 38 & 100 & 19 & 100 \\
\hline \multicolumn{9}{|l|}{ 3. Immigrants } \\
\hline Males & 10 & 50 & 6 & 46 & 31 & 49 & 14 & 52 \\
\hline Females & 10 & 50 & 7 & 54 & 32 & 51 & 13 & 48 \\
\hline \multicolumn{9}{|l|}{ 4. Emigrants } \\
\hline Males & 20 & 40 & 24 & 51 & 38 & 59 & 19 & 63 \\
\hline Females & 30 & 60 & 23 & 49 & 26 & 41 & 11 & 37 \\
\hline Born in the locality & 43 & 86 & 43 & 91 & 51 & 80 & 28 & 93 \\
\hline Born elsewhere & 7 & 14 & 4 & 9 & 13 & 20 & 2 & 7 \\
\hline Average age & 26 & - & 24 & - & 30 & - & 24 & - \\
\hline Number of localities which received emigrants & 19 & - & 16 & - & 20 & - & 9 & - \\
\hline
\end{tabular}

*Data from Carnese et al., 1996. Total population sizes: Blancura Centro: 211; Anecón Grande: 74; Cerro Policía: 188; Aguada Guzmán:108.

Table II - Fertility and mortality of the Indian populations studied.

\begin{tabular}{|lccccc|}
\hline Group analyzed & Locality & $\begin{array}{c}\text { Number of } \\
\text { women }\end{array}$ & $\begin{array}{c}\text { Number of } \\
\text { live births }\end{array}$ & $\begin{array}{c}\text { Births/Family } \\
\text { (mean } \pm \text { SD) }\end{array}$ & $\begin{array}{c}\text { Premature } \\
\text { deaths }(\%) *\end{array}$ \\
\hline All families & Blancura Centro & 42 & 225 & $5.3 \pm 1.8$ & 17 \\
& Anecón Grande & 18 & 111 & $6.1 \pm 0.5$ & 17 \\
& Cerro Policía & 38 & 206 & $5.4 \pm 0.3$ & 11 \\
& Aguada Guzmán & 22 & 106 & $4.8 \pm 0.2$ & 13 \\
& & & & & \\
Completed families ** & Blancura Centro & 24 & 162 & $6.7 \pm 3.1$ & \\
& Anecón Grande & 12 & 94 & $7.8 \pm 0.8$ & \\
& Cerro Policía & 19 & 134 & $7.0 \pm 0.8$ & \\
& Aguada Guzmán & 12 & 46 & $3.8 \pm 0.4$ & \\
& & & & & \\
Opportunity for selection $* * *$ & Blancura Centro & 0.20 & 0.22 & 0.26 & 0.46 \\
& Anecón Grande & 0.22 & 0.14 & 0.17 & 0.39 \\
& Cerro Policía & 0.11 & 0.25 & 0.28 & 0.39 \\
& Aguada Guzmán & 0.11 & 0.47 & 0.54 & 0.63 \\
\hline
\end{tabular}

*Before 15 years old. **From females $\geq 40$ years old. $* * * \operatorname{Im}=\mathrm{pd} / \mathrm{ps}$, where pd: premature deaths and ps: proportion surviving or (1-pd). If $=\mathrm{Vf} / \mathrm{x}^{2}$, where $\mathrm{Vf}$ : variance in offspring number in completed sibships and $\mathrm{x}$ : mean number of livebirths per woman who completed reproduction. I: Im + If/ps: index of opportunity for selection (Crow, 1958).

treme. The dendrogram (Figure 2) which was constructed using the blood group and mtDNA data also clearly showed two clusters, one involving Anecón Grande and Blancura Centro, and the other Aguada Guzmán and Cerro Policía.

\section{DISCUSSION}

The demographic pattern observed in these communities was typical of rural New World populations, and did not differ markedly from those observed in other Amerindian populations which adopt the same way of life (Salzano and Callegari-Jacques, 1988). The low number of children per completed family in Aguada Guzmán suggests or indicates that non-Indian fertility control measures are presently being taken in this community, with other factors, such as excessive prenatal losses, being unlikely explanations. The indices of opportunity for natural selection were of the same order of magnitude as those observed in Argentinean 
Table III - Blood group allele frequencies in the Indian populations studied.

\begin{tabular}{|lcccc|}
\hline \multirow{2}{*}{ Alleles } & \multicolumn{3}{c|}{ Populations and allele frequencies } \\
\cline { 2 - 5 } & Anecón Grande $(\mathrm{N}=61)$ & Blancura Centro* $(\mathrm{N}=95)$ & Cerro Policía (N=82) & Aguada Guzmán (N= 57) \\
\hline ABO*0 & 0.932 & 0.951 & 0.837 & 0.842 \\
ABO*A & 0.050 & 0.043 & 0.102 & 0.148 \\
ABO*B & 0.017 & 0.005 & 0.060 & 0.010 \\
FY*A & 0.638 & 0.709 & 0.534 & 0.438 \\
JK*A & 0.317 & 0.347 & 0.458 & 0.239 \\
DI*A & 0.025 & 0.032 & 0.000 & 0.017 \\
P*1 & $0.249 * *$ & 0.246 & 0.251 & 0.251 \\
LU*A & $0.031^{* *}$ & 0.032 & 0.029 & $0.031^{* *}$ \\
KELL*K & 0.000 & 0.000 & 0.000 & 0.009 \\
RH*RZ & 0.041 & 0.029 & 0.012 & 0.009 \\
RH*R1 & 0.475 & 0.518 & 0.439 & 0.535 \\
RH*R2 & 0.385 & 0.339 & 0.365 & 0.386 \\
RH*R0 & 0.098 & 0.113 & 0.183 & 0.070 \\
L*MS & 0.071 & 0.058 & 0.412 & 0.109 \\
L*Ms & 0.537 & 0.568 & 0.082 & 0.399 \\
L*NS & 0.054 & 0.016 & 0.393 & 0.075 \\
L*Ns & 0.337 & 0.358 & 0.416 \\
\hline
\end{tabular}

*Data from Carnese et al. $(1993,1996)$. **Information not available. Average of three other frequencies. The estimates of nonIndian admixture based on these frequencies were as follows: Anecón Grande, 7\%; Blancura Centro, 6\%; Cerro Policía, 12\%; Aguada Guzmán, $13 \%$. Total heterozygosity by locus was as follows, ABO: 0.20; Duffy: 0.49; Kidd: 0.47; Diego: 0.04; P: 0.40; Lutheran: 0.06; Kell: 0.004; Rh: 0.61; MNSs: 0.62.

Table IV - mtDNA haplogroups (\%) in the Indian populations studied.*

\begin{tabular}{|cccc|}
\hline $\begin{array}{l}\text { mtDNA } \\
\text { haplogroup }\end{array}$ & $\begin{array}{c}\text { Anecón } \\
\text { Grande** }\end{array}$ & $\begin{array}{c}\text { Cerro } \\
\text { Policía*** }\end{array}$ & $\begin{array}{c}\text { Aguada } \\
\text { Guzmán*** }\end{array}$ \\
\hline A & 15 & 4 & 6 \\
B & 38 & 35 & 28 \\
C & 21 & 27 & 19 \\
D & 26 & 15 & 44 \\
E & 0 & 19 & 3 \\
No. & 39 & 26 & 32 \\
\hline
\end{tabular}

* Since this information was not available for Blancura Centro, averages of the frequencies obtained in the three other populations were used to allow the inclusion of these results in the calculation of genetic distances and construction of the dendrogram. **Data from Ginther et al. (1993). ***Data from Baillet et al. (1994), where the results from the two localities were presented as a whole. No., Number of individuals studied.

Toba populations (Fortín Lavalle: 0.66; Villa Iapi: 0.42) (Palatnik, 1973; Carnese and Caratini, 1992).

Spatial analysis indicated heterogeneity for several blood group loci, with significant differences occurring in relation to ABO, MNSs and Duffy. However, this heterogeneity did not follow a regular geographical pattern, reflecting instead the dichotomy indicated earlier, which was probably related to the degree of non-Indian influence more than any other factor.

The low prevalences of $\mathrm{P}^{*} 1$ and $\mathrm{DI}^{*} \mathrm{~A}$, and high prevalence of $\mathrm{RH}^{*} \mathrm{RO}$ were significantly different from South American Indian averages (Salzano and CallegariJacques, 1988). Previous studies involving some or all of these markers have been performed in Mapuche Indians from Chile by Sandoval and Henckel (1954), Witkop and Gaiser (1960), Etcheverry et al. (1967), and Matson et al. (1967), and from Argentina by Matson et al. (1969) and Haas et al. (1985). Null or low frequencies of DI*A were observed in five Mapuche populations of the two countries, indicating that this may be a distinctive trait of this tribe. Although variable prevalences of $\mathrm{P}^{*} 1$ and $\mathrm{RH}^{*} \mathrm{RO}$ were obtained in these same groups, no generalization about them is possible at the moment.

The high frequencies of $\mathrm{RH}^{*} \mathrm{RO}$ seen in this study may be explained by admixture with African-derived persons. We previously suggested this possibility in relation to Blancura Centro (Carnese et al., 1993). Studies with serum proteins, the hemoglobin gene, and $\mathrm{Y}$ chromosome DNA markers (Weidle de Araujo et al., 1995; Kaufman et al., 1998; Bianchi et al., 1997) seem to confirm this hypothesis. Ethnohistorical investigations need to be performed to identify the sources of these African markers.

The question as to whether the mtDNA haplogroup E was present in the parental groups which colonized America is still unanswered. The absence of haplogroup E in Anecón Grande, which has an estimated non-Indian admixture of $7 \%$, and the presence in Cerro Policía and Aguada Guzmán (calculated admixture rates of 12 and 13\%, respectively) suggest that its presence reflects non-Indian gene flow. However, a close examination of the genealogies of carriers of this haplogroup revealed no indications of interethnic exchange, at least in recent generations.

In conclusion, we found significant genetic heterogeneity in a set of four populations of the same tribal origin established in an area whose linear limits do not ex- 


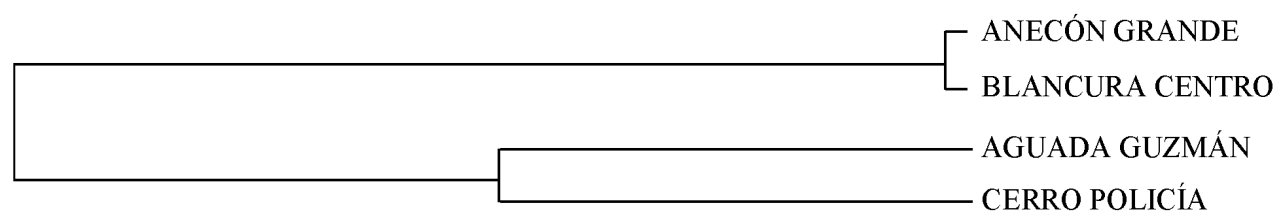

Figure 2 - Dendrogram of the Mapuche populations studied, obtained using Nei's (1973) standard genetic distances and the neighbor-joining method.

ceed $215 \mathrm{~km}$. The clear clustering of these populations into groups of two attests to the sensitivity of the demographic and genetic approaches used to detect even small differences that may be important in studies of human diversification.

\section{ACKNOWLEDGMENTS}

We thank the Consejo Nacional de Investigaciones Científicas y Técnicas (CONICET) and Conselho Nacional de Desenvolvimento Científico e Tecnológico (CNPq) for grants-in-aid and for their interchange program (Convênio de Cooperação Internacional CONICET/CNPq), which greatly helped our collaborative work. Additional financial aid was provided by the Secretaría de Ciencia y Técnica, Universidad de Buenos Aires (UBACyT) and Financiadora de Estudos e Projetos (FINEP). Laura Reboratti helped with the manuscript preparation. The authors also thank the authorities and personnel of the General Roca and Comallo Hospitals, Provincia de Río Negro, for logistical support. The Indian leaders and the subjects of the investigation were adequately informed about the aims of the study and gave their approval, which is gratefully acknowledged.

\section{RESUMO}

Dados relativos a fertilidade, mortalidade e migração de quatro comunidades de índios Mapuche localizadas em uma área linear na direção nordeste-sudoeste com $215 \mathrm{~km}$ de extensão na Província de Rio Negro, Argentina, foram associados com a informação genética fornecida por nove sistemas de grupos sangüíneos e os haplogrupos do DNA mitocondrial. Ambos os tipos de informação apontam claramente para uma dicotomia, as quatro populações sendo divididas em grupos de duas. O principal fator responsável por esta separação é provavelmente graus diferentes de mistura com não-índios. A variabilidade genética total foi muito similar em todos os grupos, aquela entre populações sendo de apenas $10 \%$ deste valor. Foi confirmada a baixa prevalência do antígeno Diego(a) entre os Mapuche. O fato de que heterogeneidade genética significativa e conjuntos populacionais diversos foram observados em uma região territorial tão pequena demonstra a sensibilidade dos enfoques demográfico e genético no esclarecimento da história humana.

\section{REFERENCES}

Adams, J. and Smouse, P.E. (1985). Genetic consequences of demographic changes in human populations. In: Diseases of Complex Etiology in Small Population (Chakraborty, R. and Szathmary, E.J.E., eds.). Alan R. Liss, New York, pp. 283-299.
Baillet, G., Rothhammer, F., Carnese, F.R., Bravi, C.M. and Bianchi, N.O. (1994). Founder mitochondrial haplotypes in Amerindian populations. Am. J. Hum. Genet. 54: 27-33.

Bianchi, N.O., Bailliet, G., Bravi, C., Carnese, F.R., Rothhammer, F., Martínez-Marignac, V. and Pena, S. (1997). Origin of Amerindian Ychromosomes as inferred by the analysis of six polymorphic markers. Am. J. Phys. Anthropol. 102: 79-89.

Caratini, A.L., Ingold, L., Crognier, E. and Carnese, F.R. (1995). Demografía genética de la población mapuche de Villa Obrera, Río Negro. Rev. Arg. Antrop. Biol. 1: 57-68.

Carnese, F.R. and Caratini, A.L. (1992). Demografía genética de una población toba de Villa Iapi, Quilmes, Prov. de Buenos Aires. Etnía 36/37: 9-28.

Carnese, F.R., Goicoechea, A.S., Rey, J., Niborsky, R.C., Kohan, A.I. and Arrayago, A.M. (1993). Grupos sanguíneos en una población mapuche de Blancura Centro, Prov. de Río Negro, Argentina. Bol. Soc. Esp. Antrop. Biol. 14:31-39.

Carnese, F.R., Caratini, A.L., Goicoechea, A.S., Weimer, T.A., Franco, M.H.L.P., Hutz, M.H. and Salzano, F.M. (1996). Demography and blood genetics of Argentinian Mapuche Indians. Int. J. Anthropol. 11: 31-40.

Chakraborty, R. (1975). Estimation of race admixture. A new method. Am. J. Phys. Anthropol. 42: 507-512.

Crow, J.F. (1958). Some possibilities for measuring selection intensities in man. Hum. Biol. 30: 1-13.

Etcheverry, R., Guzmán, C., Hille, A., Nagel, R., Covarrubias, E., Regonesi, C., Miranda, M. and Durán, N. (1967). Investigación de grupos sanguíneos y otros caracteres genéticos sanguíneos en indígenas de Chile. I: en atacameños y mapuches. Rev. Med. Chile 95: 599-604.

Ginther, C., Corach, D., Penacino, A., Rey, J.A., Carnese, F.R., Hutz, M.H., Anderson, A., Just, J., Salzano, F.M. and King, M.C. (1993). Genetic variation among the Mapuche Indians from the Patagonian region of Argentina: mitochondrial DNA sequence variation and allele frequencies of several nuclear genes. In: DNA Fingerprinting: State of the Science (Pena, S.D.J., Chakraborty, R.M., Epplen, J.T. and Jeffrey, A.J., eds). Birkhauser Verlag, Basel, pp. 211-219.

Haas, E.J.C., Salzano, F.M., Araujo, H.A., Grossman, F., Barbetti, A., Weimer, T.A., Franco, M.H.L.P., Verruno, L., Nasif, O., Morales, V.H. and Arienti, R. (1985). HLA antigens and other genetic markers in the Mapuche Indians of Argentina. Hum. Hered. 35: 306-313.

Kaufman, L., Carnese, F.R., Goicoechea, A.S., Dejean, C.B., Salzano, F.M. and Hutz, M.H. (1998). Beta-globin gene cluster haplotypes in the Mapuche Indians of Argentina. Genet. Mol. Biol. 21: 435-437.

Matson, G.A., Sutton, H.E., Etcheverry, R., Swanson, J. and Robinson, A. (1967). Distribution of hereditary blood groups among Indians in South America. IV. In Chile. Am J. Phys. Anthropol. 27: 157-193.

Matson, G.A., Sutton, H.E., Swanson, J. and Robinson, A. (1969). Distribution of hereditary blood groups among Indians in South America. VII. In Argentina. Am. J. Phys. Anthropol. 30: 61-83.

Nei, M. (1973). Analysis of gene diversity in subdivided populations. Proc. Natl. Acad. Sci. USA 70: 3321-3332.

Nei, M. (1978). Estimation of average heterozygosity and genetic distance from a small number of individuals. Genetics 89: 583-590.

Nei, M. (1986). Definition and estimation of fixation indices. Evolution 40: 643-645.

Nei, M. and Roychoudhury, A.K. (1993). Evolutionary relationships of human populations on a global scale. Mol. Biol. Evol. 10: 927-943.

Nei, M., Tajima, F. and Tateno, Y. (1983). Accuracy of estimated phylogenetic trees from molecular data. J. Mol. Evol. 19: 927-943.

Ota, T. (1993). DISPAN: Genetic Distance and Phylogenetic Analysis Uni- 
versity Park: Institute of Molecular and Evolutionary Genetics. The Pennsylvania State University, University Park, PA, USA.

Palatnik, M. (1973). Demografía: parámetros de implicancia genética. In: Simposio sobre Genética de la Población Toba del Chaco Argentino (Palatnik, M., ed.). Fundación Miguel Lillo, Tucumán, pp. 8-21.

Reed, T.E. and Schull, W.J. (1968). A general maximum likelihood estimation program. Am. J. Hum. Genet. 20: 579-580.

Saitou, N. and Nei, M. (1987). The neighbor-joining method: a new method for reconstructing phylogenetic trees. Mol. Biol. Evol. 4: 406-425.

Salzano, F.M. and Callegari-Jacques, S.M. (1988). South American Indians. A Case Study in Evolution. Clarendon Press, Oxford.

Sandoval, L. and Henckel, C. (1954). The ABO, MNS, and Rh-Hr blood groups of the Mapuche Indians of Cautin Province, Chile. Hum.
Biol. 26: 324-329.

Valls, A. (1975). Seroantropología de la población española. Rev. Univ. Compl. 24: 111-139.

Vapñarsky, C.A. (1983). Pueblos del Norte de la Patagonia 1779-1957. Centro de Estudios Urbanos y Regionales, Buenos Aires.

Weidle de Araujo, E., Ghinzelli, A.C., Franco, M.H., Carnese, F.R. and Salzano, F.M. (1995). Polimorfismos protéicos em indios Mapuche da Argentina. Rev. Bras. Genét. 18 (Suppl.): 335.

Witkop Jr., C.J. and Gaiser, J. (1960). Genetic Blood Studies. A Report by the Interdepartamental Committee on Nutrition for National Defense. National Institutes of Health, Bethesda, pp. 317-320.

(Received June 15, 1999) 